\title{
Potential of biogas production from swine manure in South Korea
}

\author{
Dong Jin $\mathrm{Lee}^{1} \cdot \mathrm{Ji}$ Su Bae ${ }^{1} \cdot$ Dong Cheol $\mathrm{Seo}^{2}$
}

Received: 4 July 2018/ Accepted: 28 July 2018/Published online: 9 August 2018

(C) The Korean Society for Applied Biological Chemistry 2018

\begin{abstract}
This study is to compare biogas potentials with the theoretical methane yields of swine manure from livestock farm (LF) and in situ biogasification facilities treating swine manure. In the case of LF, theoretical methane yield based on VS and CODcr by element analysis was $0.39 \mathrm{Sm}^{3} \mathrm{CH}_{4} / \mathrm{kg}$ and $30.96 \mathrm{Sm}^{3} \mathrm{CH}_{4} /$ ton, respectively. For the in situ biogasification facilities, theoretical methane yield based on VS and CODcr by element analysis was $0.30 \mathrm{Sm}^{3} \mathrm{CH}_{4} / \mathrm{kg}$ and $8.28 \mathrm{Sm}^{3} \mathrm{CH}_{4} /$ ton, respectively. Theoretical methane yields based on the weight of swine manure from LF were about three times higher than those from in situ facilities (ISF). As a result, when swine manure has reached the ISF, the decrement of about $24.5-73.3 \%$ in the methane yield could be seen due to the 3-6-month stationing of swine manure in the storage tank of LF. In order to improve the biogasification efficiency of swine manure, it is important to maintain high concentration of swine manure during the collection process from LF.
\end{abstract}

Keywords Anaerobic digestion - Livestock farm . Methane yield $\cdot$ Swine manure

Ji Su Bae

jisubae88@gmail.com

$\bowtie$ Dong Cheol Seo

drseodc@gmail.com

1 Environmental Resources Research Department, National Institute of Environmental Research, Environmental Research Complex, Incheon 404-708, Republic of Korea

2 Division of Applied Life Science (BK21 Plus) and Institute of Agriculture and Life Science, Gyeongsang National University, Jinju 52828, Republic of Korea

\section{Introduction}

Land filling and ocean dumping of organic waste such as food waste, swine manure have been prohibited since 2005 and 2013, respectively [1]. Swine manure was produced approximately $173,052 \mathrm{~m}^{3} \mathrm{day}^{-1}$ in 2012 , and $89.3 \%$ of that from the entire livestock farm (LF) had been recycled by manure management methods such as composting, biogasification. [2-4]. In Korea, the production of swine manure has been increased continuously along with the industrialization and specialization of the domestic LF [5-7]. Swine manure was generated approximately $173,052 \mathrm{~m}^{3}$ day $^{-1}$ from $\operatorname{LF}[2,3]$. Due to the odor and aesthetic impact of swine manure, treatment methods have been studied endlessly and issued. The rest of $9.7 \%$ of swine manure in breeding farms was handled by entrusting the external vendors [8-10].

Among the various treatments, anaerobic biogasification has attracted attention for producing the renewable energy such as methane gas. With the cooperation of various government departments, the biogasification of swine manure is being actively pursued recently. Ministry of Agriculture, Food and Rural Affairs in Korea settled the master plan and suggested an execution scheme on animal manure energization [8, 9]. Ministry of Environment in Korea has planned to construct 22 new biogasification facilities until 2020 investing 722.5 billion KRW [11, 12].

In Korea, management of swine manure from LF is very different from that in EU countries. Swine manure of LF in Korea generally goes through the slurry storage tank, total intermediate storage tanks of each swine manure type and final storage tank coming from intermediate storage tanks. On the other hand, swine manure of LF in EU countries is directly projected into in situ biogasification facilities with 
approximately a few days stationing in the storage tank. Various dissimilar storage types of swine manure between Korea and EU countries might give an effect on biogasification efficiency [13].

Nevertheless, recent situation about increment in biogasification facilities, most of biogasification facilities treating swine manure do not meet the normal capacity utilization by itself. In particular, the average biogas production amount per ton in ongoing biogasification facilities was $9.6 \mathrm{~m}^{3}$ which was not effective compared with other organic wastes including food waste $\left(109.7 \mathrm{~m}^{3}\right)$ [14]. Therefore, the purpose of this study was to evaluate justification of the low-efficient methane productivity and to find out alternatives for improving the biogasification efficiency in in situ facilities (ISF) compared with LF.

\section{Materials and methods}

\section{Outline of livestock farms and biogasification facilities}

The outline of LF and biogasification facilities for this study is described in Tables 1 and 2. Fifteen LF breeding pigs from different locations were selected for this investigation. These farms were chosen by various types of breeding pig, shape and scale of farms, etc. Sampling was conducted depending on classification of the growth sequence of pigs: Pig 1 (25-60-day breeding, piglets), Pig 2 (60-116-day breeding), Pig 3 (116-189-day breeding, before shipping to butchery) and Pig 4 (sows including pregnant pigs) [15]. Each sample was collected from respective swine manure storage tanks of explained before breeding pigs and the last combined liquefied fertilizer tank in LF.

Three ongoing biogasification facilities treating swine manure independently were chosen as target for this study. The precision diagnostication of facilities was conducted for sampling and inspecting operating factors such as volatile fatty acids (VFAs), volatile solids (VS), total solids (TS), element contents (carbon, nitrogen, sulfur and hydrogen), nutrients (carbohydrate, protein and fat). Sampling was carried out in all seasons and gathered from the input storage tank of facilities. All of samples from ISF were immediately stored in a refrigerator until they were analyzed. All of swine manure samples of LF and ISF were frozen and preserved in the refrigerator until analysis.

\section{Analytical methods}

All of samples collected from LF and ISF were taken on the regular basis for determining physicochemical properties. The detailed analysis list is as follows: TS, VS, moisture contents, chemical oxygen demand (CODcr), total nitrogen $(\mathrm{TN})$, ammonium nitrogen $\left(\mathrm{NH}_{3}-\mathrm{N}\right)$, total phosphorus (TP) and phosphate phosphorus $\left(\mathrm{PO}_{4}-\mathrm{P}\right)$

Table 1 Outline of livestock farms

\begin{tabular}{llll}
\hline Samples & Bottom type & Breeding type of livestock (pig) & Remarks \\
\hline GS1 & Slurry, open type & Pig 1, Pig 2, Pig 3 & Conduct solid-liquid separation of swine manure \\
HD1 & Slurry, open type & Pig 1, Pig 2, Pig 3, Pig 4 & Conduct solid-liquid separation of swine manure \\
HD2 & Slurry & Pig 1, Pig 2, Pig 3, Pig 4 & \\
HD3 & Slurry, open type & Pig 1, Pig 3 & \\
HY1 & Slurry, open type & Pig 1, Pig 3, Pig 4 & \\
HY2 & Slurry, closed type & Pig 3, Pig 4 & Conduct solid-liquid separation of swine manure \\
HY3 & Scraper & Pig 1, Pig 2, Pig 3, Pig 4 & Conduct solid-liquid separation of swine manure \\
YS1 & Slurry, open type, closed type & Pig 1, Pig 2, Pig 3, Pig 4 & Conduct solid-liquid separation of swine manure \\
& & Pig 1, Pig 2, Pig 3, Pig 4 & Liquified fertilizer by aeration of swine manure \\
SC1 & Slurry, open type & Pig 1, Pig 2, Pig 3, Pig 4 & Conduct solid-liquid separation of swine manure \\
SC2 & Slurry, open type & Pig 2, Pig 3, Pig 4 & Conduct solid-liquid separation of swine manure \\
JC1 & Slurry, open type, closed type & Pig 2, Pig 4 & Conduct solid-liquid separation of swine manure \\
JC2 & Open type & Pig 1, Pig 3, Pig 4 & \\
JC3 & Slurry, closed type & Pig 1, Pig 2, Pig 4 & Demonstration of sawdust/soil filtration \\
JC4 & Terraced slurry, open type & Pig 1, Pig 2, Pig 3 & Conduct solid-liquid separation of swine manure \\
US1 & Slurry, open type & Conduct solid-liquid separation of swine manure
\end{tabular}

Classification by growth sequence of pig [15]; Pig 1: 25-60-day breeding pigs; Pig 2: 60-116 days; Pig 3: 116-189 days-before shipping to butchery; Pig 4: sows (including pregnant pigs) 
Table 2 Outline of target biogasification facilities treating swine manure

\begin{tabular}{|c|c|c|c|c|c|c|c|}
\hline Samples & Type of digestion & $\begin{array}{l}\text { Design capacity of digester } \\
\left(\text { ton day }{ }^{-1} \text { ) }\right.\end{array}$ & $\begin{array}{l}\text { Volume of } \\
\text { digester }\left(\mathrm{m}^{3}\right)\end{array}$ & $\begin{array}{l}\text { HRT } \\
\text { (day) }\end{array}$ & $\begin{array}{l}\text { Temp } \\
\left({ }^{\circ} \mathrm{C}\right)\end{array}$ & $\mathrm{pH}$ & $\begin{array}{l}\text { Organic loading rate }(\mathrm{kg} \\
\mathrm{VS} / \mathrm{m}^{3} \text { day) }\end{array}$ \\
\hline SM1 & $\begin{array}{l}\text { Mesophilic, } \\
\text { single stage }\end{array}$ & 20 & 400 & 32 & - & - & 1.2 \\
\hline SM2 & $\begin{array}{l}\text { Mesophilic, } \\
\text { single stage }\end{array}$ & 30 & 1200 & 30 & $\begin{array}{l}35.4 \\
\quad( \pm 1.5)\end{array}$ & $\begin{array}{l}7.3 \\
( \pm 0.2)\end{array}$ & 0.44 \\
\hline SM3 & $\begin{array}{l}\text { Mesophilic, } \\
\text { single stage }\end{array}$ & 50 & 2400 & 48 & $\begin{array}{l}31.1 \\
\quad( \pm 3.6)\end{array}$ & $\begin{array}{l}7.2 \\
\quad( \pm 0.4)\end{array}$ & 1.22 \\
\hline
\end{tabular}

$S M$ in situ biogasification facility treating swine manure

[16, 17]. Organic constituents (carbohydrate, protein and fat) were carried out according to Korean Food Standard Codex [18, 19].

Element contents were analyzed for the calculation of theoretical methane yield based on VS and CODcr. Samples for element contents analysis were completely dried at $105{ }^{\circ} \mathrm{C}$ for $4 \mathrm{~h}$ in order to eliminate the internal moisture. The dried samples were pulverized to fine particles of less than $0.05 \mathrm{~mm}$. Element contents such as carbon (C), hydrogen $(\mathrm{H})$, nitrogen $(\mathrm{N})$ and sulfur $(\mathrm{S})$ were determined using the elemental analyzer. Elemental analyzer (Leco Co. 628 series, 2012) was equipped with non-dispersive infrared cells, thermal conductivity cell and sulfur infrared detection cell and utilized to detect $\mathrm{H}_{2} \mathrm{O}, \mathrm{CO}_{2}, \mathrm{~N}_{2}$ and $\mathrm{SO}_{2}$ oxidized element contents present in samples. The amount of separated gases from oxidized samples in the analytical equipment was converted into \% contents on the basis of the concentration of reference materials, EDTA and coal.

VFAs were analyzed according to Standard methods (5560 D-gas chromatographic method 4.a.) [16]. Samples were pre-treated by extraction with diethyl ether to determine VFAs contents by gas chromatography. Gas chromatography was composed of FID and DB-FFAP column $(25 \mathrm{~m} \times 0.32 \mathrm{~mm} \times 0.5 \mu \mathrm{m})$ and operated at $240{ }^{\circ} \mathrm{C}$ in $1.0 \mathrm{~mL} \mathrm{m^{-1 }}$ flow rate condition.

\section{Calculation of theoretical methane yield}

Along with microbiology of anaerobic digestion process, organic waste (swine manure) consumed by microorganisms was degraded and converted into the following end products: methane, carbon dioxide, ammonia gas and water. Equation (1) utilizes element contents $(\mathrm{C}, \mathrm{H}, \mathrm{O}$ and $\mathrm{N})$ for estimating the theoretical methane yield from organic waste [20-22].

$$
\begin{aligned}
& \mathrm{C}_{n} \mathrm{H}_{a} \mathrm{O}_{b} \mathrm{~N}_{c}+[(4 n-a-2 b-3 c) / 4] \mathrm{H}_{2} \mathrm{O} \\
& \quad \rightarrow[(4 n+a-2 b-3 c) / 8] \mathrm{CH}_{4} \\
& +[(4 n-a+2 b+3 c) / 8] \mathrm{CO}_{2}+\mathrm{cNH}_{4}
\end{aligned}
$$

In addition, Rittmann and McCarty [23] suggested the substrate partitioning and cellular yield to anaerobic stoichiometry of anaerobic treatment. Equation (2) considers two kinds of portions, $f_{\mathrm{e}}$ used to generate energy and $f_{\mathrm{s}}$ constituted of microbial cells.

$$
\begin{aligned}
& \mathrm{C}_{n} \mathrm{H}_{a} \mathrm{O}_{b} \mathrm{~N}_{c}+\left[2 n+a-b-9 \mathrm{~d} f_{\mathrm{s}} / 20-\mathrm{d} f_{\mathrm{e}} / 4\right] \mathrm{H}_{2} \mathrm{O} \\
& \rightarrow\left[\mathrm{d} f_{\mathrm{e}} / 8\right] \mathrm{CH}_{4}+\left[n-c-d f_{s} / 5-d f_{e} / 8\right] \mathrm{CO}_{2} \\
& \quad+\left[\mathrm{d} f_{\mathrm{s}} / 20\right] \mathrm{C}_{5} \mathrm{H}_{7} \mathrm{O}_{2} \mathrm{~N}+\left[c-\mathrm{d} f_{\mathrm{s}} / 20\right] \mathrm{NH}_{4}^{+} \\
& \quad+\left[c-\mathrm{d} f_{\mathrm{s}} / 20\right] \mathrm{HCO}_{3}^{-} \\
& d=4 n+a-2 b-3 c
\end{aligned}
$$

Table 3 Generic parameters of two distinct methanogens

\begin{tabular}{lll}
\hline & Acetate fermenters $(72 \%)$ & Hydrogen oxidizers (28\%) \\
\hline Electron donors & Acetate & $\mathrm{H}_{2}$ and formate \\
Electron acceptors & Acetate & $\mathrm{CO}_{2}$ \\
Carbon sources & Acetate & $\mathrm{CO}_{2}$ \\
$f_{\mathrm{s}}^{0}$ & 0.05 & 0.08 \\
$b\left(\mathrm{~d}^{-1}\right)$ & 0.03 & 0.03 \\
{$\left[\theta_{x}^{\text {min }}\right] \lim (\mathrm{d})$} & 4 & 0.76 \\
$f_{\mathrm{s}}$ & 0.05 & 0.08 \\
$f_{\mathrm{e}}$ & 0.95 & 0.92 \\
\hline
\end{tabular}

Description of signs and abbreviations: $f_{\mathrm{s}}^{0}$ : cell synthesis fraction of electron donor by micro-organisms; $f_{\mathrm{e}}^{0}$ : energy production fraction of electron donor; $b$ : decay rate of microorganisms; $\left[\theta_{x}^{\min }\right]$ lim: limiting value of minimum solids retention time (SRT) 
In this study, theoretical methane yield was calculated by generic coefficients of two distinct methanogens shown in Table 3 and used in stoichiometric Eq. (2). On the basis of methanogenesis metabolism (Gujer and Zehner) [24], organic matter was converted to $\mathrm{CH}_{4}$ and $\mathrm{CO}_{2}$ by the acetate fermenters $(72 \%)$ and hydrogen oxidizers $(28 \%)$. Equation (4) meaning the theoretical methane yield based on VS by elements contents could be computed in reference to above formula (2) and (3). Theoretical methane yield expressed as STP.L.CH $/ \mathrm{g}$.CODcr was calculated by Eq. (5) concerning the ratio of CODcr/VS. In this study, molecular formulas using the results of elements analysis in this study were applied to the theoretical methane yield.

Theoretical methane gas production $\left(\mathrm{STP} \mathrm{L} \cdot \mathrm{CH}_{4} / \mathrm{g} \cdot \mathrm{VS}\right.$ )

$$
=\frac{22.4 \times f_{\mathrm{e}} \times(4 a+b-2 c-3 d) / 8}{12 a+b+16 c+14 d}
$$

Theoretical methane gas production (STP L $\left.\cdot \mathrm{CH}_{4} / \mathrm{g} \cdot \mathrm{CODcr}\right)$

$$
=\frac{22.4 \times f_{\mathrm{e}} \times(4 a+b-2 c-3 d) / 8}{32(a+b / 4-c / 2-3 d / 4)}
$$

\section{Results and discussion}

\section{Characterization of swine manure in LF and ISF}

Table 4 presents characteristics of swine manure from LF and ISF. Swine manure has a different distribution of concentration according to the source and the type of LF. In particular, the swine manure discharged from the large-scale farms contains high organic matters and solids contents [5, 20]. Results of TS, VS and VS/TS tended to increase according to growth of pig in LF. Except for Pig 4 representing sows and pregnant pigs, $\mathrm{CODcr}, \mathrm{TN}, \mathrm{NH}_{3}-\mathrm{N}, \mathrm{TP}$ and $\mathrm{PO}_{4}-\mathrm{P}$ showed a tendency to increase the concentration in accordance with the growing sequence of pigs. The average analysis values of LF were: TS-10.6\%, VS-7.9\%, CODcr-151,375 mg L ${ }^{-1}$, $\mathrm{TN}-6804 \mathrm{mg} \mathrm{L}^{-1}, \quad \mathrm{NH}_{3}-\mathrm{N}-4403 \mathrm{mg} \mathrm{L}^{-1}, \quad \mathrm{TP}-$ $2187 \mathrm{mg} \mathrm{L}^{-1}$ and $\mathrm{PO}_{4}-\mathrm{P}-1383 \mathrm{mg} \mathrm{L}^{-1}$. The storage tank in LF showed the similar values compared with averages of LF: TS- $11.1 \%$, VS-8.3\%, VS/TS-72.5\%, CODcr$145,725 \mathrm{mg} \mathrm{L}^{-1}, \quad \mathrm{TN}-6521 \mathrm{mg} \mathrm{L}^{-1}$ and $\mathrm{NH}_{3}-\mathrm{N}-$ $4122 \mathrm{mg} \mathrm{L}^{-1}$. It means that there is a corresponding correlation between concentrations of decomposable organic matter at the storage tank and average values in LF and confirms that the average value gas a representativeness among characteristics of swine manure in LF.

As appeared in Table 4, the average contents values of TS, VS and CODcr of swine manure from ISF were 3.9, $2.9 \%$ and $49,133 \mathrm{mg} \mathrm{L}^{-1}$, respectively. These values showed a decrement of approximately one-third of organic compound contrasting with mean values of swine manure from LF. However, VS/TS ratio, $72.6 \%$, means organic content is analogous with the result of ISF, $71.8 \%$. The nitrogen component such as $\mathrm{NH}_{3}-\mathrm{H}$ could be acting as inhibitors to anaerobic digester $[25,26]$. The average concentration of $\mathrm{NH}_{3}-\mathrm{H}$ and $\mathrm{TN}$ was 2920 and $4862 \mathrm{mg} \mathrm{L}^{-1}$, respectively. Those values had higher contents than the organic materials of typical anaerobic digestion system such as food waste, food waste leachate, sewage sludge. The TP and $\mathrm{PO}_{4}-\mathrm{P}$ concentrations of swine manure in ISF were 708 and $442 \mathrm{mg} \mathrm{L}^{-1}$, respectively.

\begin{tabular}{|c|c|c|c|c|c|c|c|c|}
\hline Samples & TS $(\%)$ & VS $(\%)$ & VS/TS (\%) & CODcr $\left(\mathrm{mg} \mathrm{L}^{-1}\right)$ & $\mathrm{TN}\left(\mathrm{mg} \mathrm{L}^{-1}\right)$ & $\mathrm{NH}_{3}-\mathrm{N}\left(\mathrm{mg} \mathrm{L}^{-1}\right)$ & $\mathrm{TP}\left(\mathrm{mg} \mathrm{L}^{-1}\right)$ & $\mathrm{PO}_{4}-\mathrm{P}\left(\mathrm{mg} \mathrm{L}^{-1}\right)$ \\
\hline \multicolumn{9}{|l|}{$L F$} \\
\hline Pig 1 & 5.6 & 4.0 & 67.5 & 120,908 & 5094 & 3372 & 798 & 563 \\
\hline Pig 2 & 11.4 & 8.7 & 74.9 & 155,711 & 7808 & 5214 & 2720 & 1885 \\
\hline Pig 3 & 12.5 & 9.2 & 12.5 & 220,480 & 8885 & 6479 & 2830 & 1769 \\
\hline Pig 4 & 13.3 & 10.2 & 75 & 115,481 & 5826 & 2702 & 3285 & 1794 \\
\hline ST & 11.1 & 8.3 & 72.5 & 145,725 & 6521 & 4122 & 1877 & 1176 \\
\hline $\operatorname{Avg}(\mathrm{LF})$ & 10.6 & 7.9 & 71.8 & 151,375 & 6804 & 4403 & 2187 & 1383 \\
\hline \multicolumn{9}{|l|}{$I S F$} \\
\hline SM 1 & 4.1 & 3.2 & 75.9 & 57,623 & 5754 & 3043 & 766 & 569 \\
\hline SM 2 & 3.6 & 2.5 & 68.8 & 51,850 & 4656 & 3060 & 781 & 428 \\
\hline SM 3 & 3.9 & 2.9 & 72.9 & 37,926 & 4176 & 2656 & 573 & 347 \\
\hline Avg (ISF) & 3.9 & 2.9 & 72.6 & 49,133 & 4862 & 2920 & 708 & 442 \\
\hline
\end{tabular}

Table 4 Characteristics of swine manure in livestock farm and in situ facilities

Classification by growth sequence of pig [15]; Pig 1: 25-60-day breeding pigs; Pig 2: 60-116 days; Pig 3: 116-189 days-before shipping to butchery; Pig 4: sows (including pregnant pigs)

$L F$ livestock farms breeding pigs, $I S F$ in situ biogasification facilities treating swine manure, $S T$ storage tank, Avg average value, $S M$ in situ biogasification facility treating swine manure 
Fig. 1 VFAs concentration of swine manure in livestock farm and in situ facilities. $L F$

livestock farms breeding pigs, $I S F$ in situ biogasification facilities treating swine manure. $S T$ storage tank, $A v g$ average value, $S M$ in situ biogasification facility treating swine manure, classification by growth sequence of pig [15], Pig 1:

25-60-day breeding pigs, Pig 2: 60-116 days, Pig 3:

116-189 days-before shipping to butchery, Pig 4: sows (including pregnant pigs)

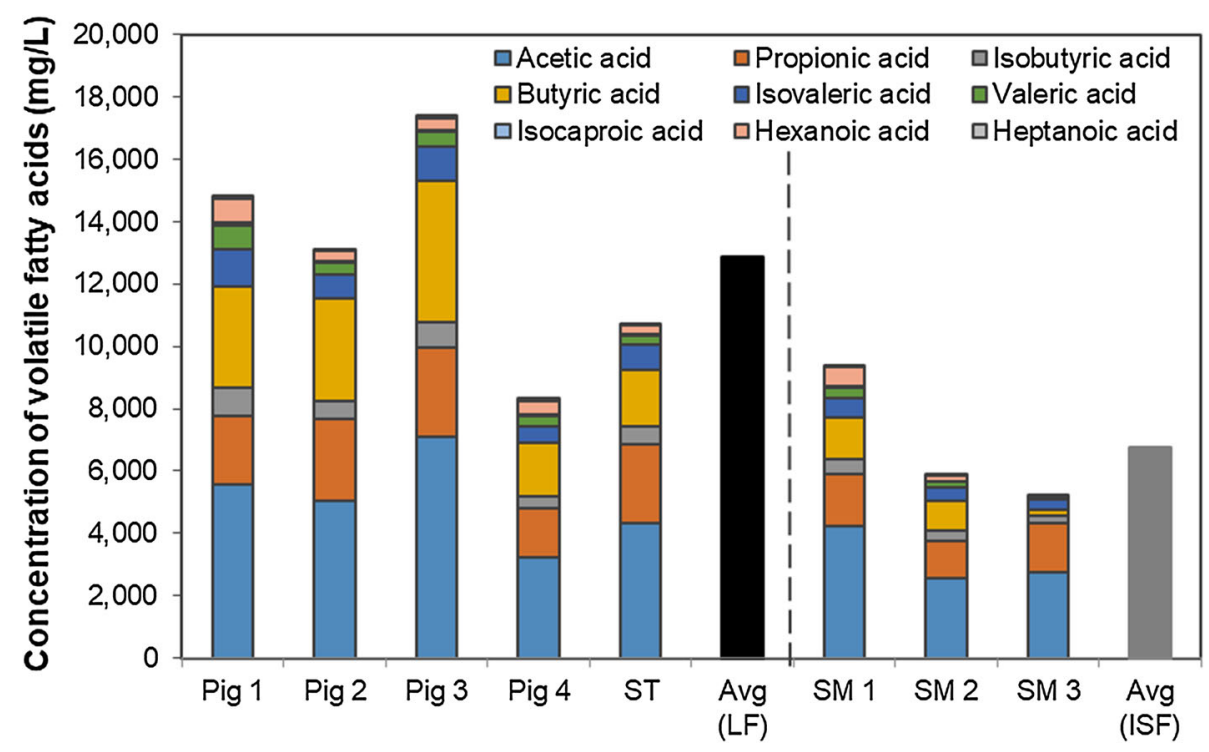

Fig. 2 Weights by organic constituents of swine manure in livestock farm and in situ facilities. $S T$ storage tank, $S M$ in situ biogasification facility treating swine manure, classification by growth sequence of pig [15]; Pig 1: 25-60-day breeding pigs, Pig 2: 60-116 days, Pig 3:

116-189 days-before shipping to butchery, Pig 4: sows (including pregnant pigs)

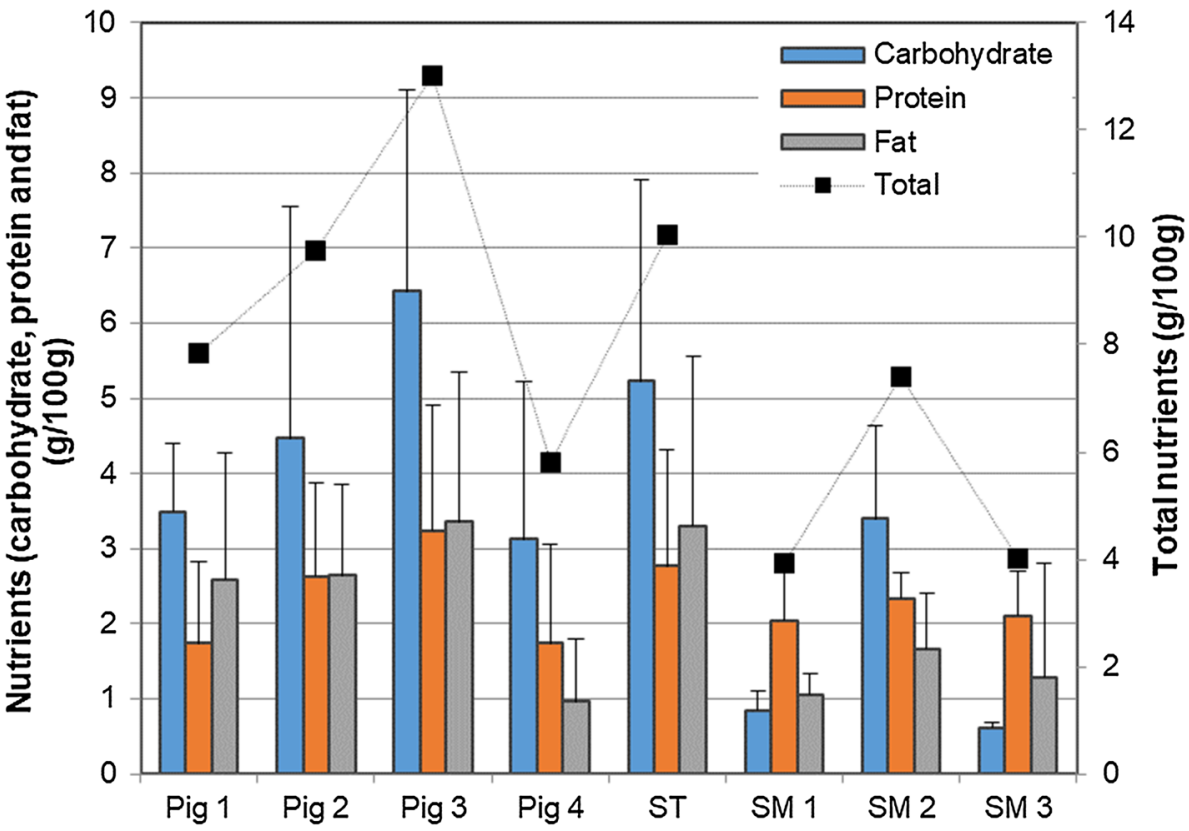

including the pregnant pigs and sows bred in stall bottom type popularly for convenience of parturition and domestication. In ISF, each of total VFAs concentration ranged from 5163 to $9360 \mathrm{mg} \mathrm{L}^{-1}$ depending on process features of incoming organic matters into the biogasification facilities. The average VFAs content was $6820 \mathrm{mg} \mathrm{L}^{-1}$ corresponding to the mean value of LF, $52.9 \%$.

\section{Organic constituents (carbohydrate, protein and fat)}

Properties of organic constituents are illustrated in Fig. 2. The average weight of protein, fat and carbohydrate of LF 
was $2.42,2.57$ and $4.55 \mathrm{~g} / 100 \mathrm{~g}$, respectively. The average weight of protein, fat and carbohydrate of ISF was 2.16, 1.34 and $1.62 \mathrm{~g} / 100 \mathrm{~g}$, respectively. Total nutrient contents from LF and ISF were 9.54 and $5.12 \mathrm{~g} / 100 \mathrm{~g}$, respectively. Through these results, fat, carbohydrate and total nutrients were degraded about $48.0,64.4$ and $46.4 \%$, respectively. It means that swine manure was decomposed in advance

Table 5 Elements analysis of swine manure in livestock farm and in situ facilities

\begin{tabular}{lllllll}
\hline Samples & $\mathrm{C}$ & $\mathrm{H}$ & $\mathrm{O}$ & $\mathrm{N}$ & $\mathrm{S}$ & $\mathrm{C} / \mathrm{N}$ ratio \\
\hline LF & & & & & & \\
Pig 1 & 40.1 & 6.1 & 16.2 & 3.8 & 1.3 & 10.6 \\
Pig 2 & 43.6 & 6.7 & 20.0 & 3.5 & 1.1 & 12.4 \\
Pig 3 & 40.1 & 6.1 & 18.6 & 3.6 & 1.3 & 11.3 \\
Pig 4 & 41.0 & 6.2 & 23.8 & 3.3 & 0.6 & 12.6 \\
ST & 44.2 & 6.7 & 17.4 & 3.2 & 0.9 & 14.4 \\
Avg (LF) & 42.1 & 6.4 & 18.7 & 3.5 & 1.1 & 12.5 \\
ISF & & & & & & \\
SM 1 & 40.1 & 5.4 & 24.1 & 5.4 & 1.0 & 8.6 \\
SM 2 & 39.1 & 5.6 & 19.9 & 3.6 & 0.8 & 11.0 \\
SM 3 & 36.3 & 5.3 & 27.1 & 3.2 & 1.1 & 11.5 \\
Avg (ISF) & 35.5 & 5.1 & 22.5 & 3.9 & 0.9 & 9.7
\end{tabular}

Classification by growth sequence of pig [15]; Pig 1: 25-60-days breeding pigs; Pig 2: 60-116 days; Pig 3: 116-189 days-before shipping to butchery; Pig 4: sows (including pregnant pigs)

$L F$ livestock farms breeding pigs, $I S F$ in situ biogasification facilities treating swine manure, $S T$ storage tank, $A v g$ average value, $S M$ in situ biogasification facility treating swine manure during transportation from LF to biogasification facilities. Moreover, it is estimated that swine manure was acquired in condition of inapposite agitation at the storage tank in LF during the collection process. Among the organic constituents, protein had the lowest difference between LF and in situ biogasification facilities.

\section{Elements content analysis}

Table 5 presents the elements analysis of swine manure in LF and ISF. The average elements contents (\%) of LF were 42.1 on carbon, 6.4 on hydrogen, 3.5 on nitrogen, 1.1 on sulfur and 18.7 on oxygen. The average values of ISF were 35.5 on carbon, 5.1 on hydrogen, 3.9 on nitrogen, 0.9 on sulfur and 22.5 on oxygen. Elements analysis results showed that ISF values are lower than LF except for nitrogen and oxygen in mean values. The carbon/nitrogen $(\mathrm{C} / \mathrm{N})$ ratio of LF and ISF was 12.5 and 9.7, respectively. Considering the nitrogen contents (\%) between LF and ISF almost identical, pre-decomposition of carbon sources in the swine manure occurred in the process of transportation to facilities.

\section{Theoretical methane yield (TMY) in LF and ISF}

All of the theoretical methane yields were calculated assuming $100 \%$ removal efficiency of swine manure. As presented in Table 6, theoretical methane yield of LF (TMYLF) and ISF (TMYISF) was estimated depending on the proportions of element contents. Theoretical methane
Table 6 Theoretical methane yield by elements analysis of swine manure

\begin{tabular}{llllll}
\hline Samples & \multicolumn{2}{l}{ Methane yield based on VS $\left(\mathrm{Sm}^{3} \mathrm{CH}_{4} / \mathrm{kg}\right)$} & & \multicolumn{2}{l}{ Methane yield based on CODcr $\left(\mathrm{Sm}^{3} \mathrm{CH}_{4} / \mathrm{kg}\right)$} \\
\cline { 2 - 3 } & TMY & TMY $(\mathrm{m})$ & & & \\
\hline PMY & & & & \\
Pig 1 & 0.44 & 0.41 & 0.35 & 0.33 \\
Pig 2 & 0.41 & 0.38 & 0.35 & 0.33 \\
Pig 3 & 0.40 & 0.38 & 0.35 & 0.33 \\
Pig 4 & 0.34 & 0.32 & 0.35 & 0.33 \\
ST & 0.46 & 0.43 & 0.35 & 0.33 \\
Avg (LF) & 0.41 & 0.39 & 0.35 & 0.33 \\
ISF & & & & 0.33 \\
SM 1 & 0.31 & 0.29 & 0.35 & 0.33 \\
SM 2 & 0.37 & 0.35 & 0.35 & 0.33 \\
SM 3 & 0.27 & 0.26 & 0.35 & 0.33 \\
Avg (ISF) & 0.31 & 0.30 & 0.35 &
\end{tabular}

Classification by growth sequence of pig [15]; Pig 1: 25-60-day breeding pigs; Pig 2: 60-116 days; Pig 3: 116-189 days-before shipping to butchery; Pig 4: sows (including pregnant pigs)

$L F$ livestock farms breeding pigs, $I S F$ in situ biogasification facilities treating swine manure, $S T$ storage tank, $A v g$ average value, $S M$ in situ biogasification facility treating swine manure, $T M Y$ theoretical methane yield, $\operatorname{TMY}(\mathrm{m})$ total sum of theoretical methane yield modified with generic parameters of methanogens (acetate fermenters and hydrogen oxidizers) 

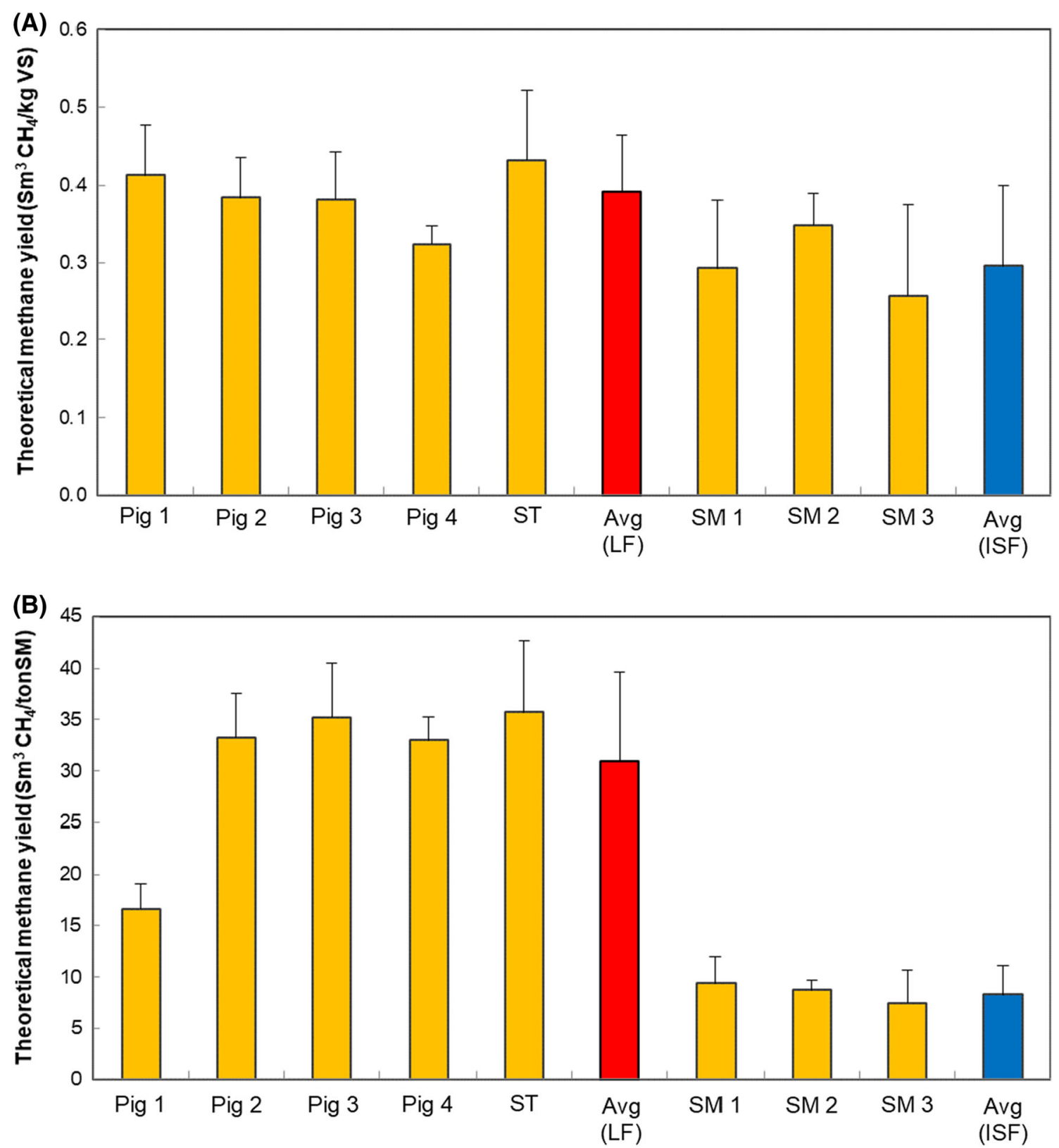

Fig. 3 Results of theoretical methane yield. $L F$ livestock farms breeding pigs, $I S F$ in situ biogasification facilities treating swine manure, $S T$ storage tank, $A v g$ average value, $S M$ in situ biogasification facility treating swine manure, classification by growth sequence of

yield based on VS and CODcr in this study was modified with microbial generic parameters of methanogens: acetate fermenters and hydrogen oxidizers in Table 3. On the basis of series metabolism resulting in methanogenesis, complex organic compounds containing swine manure were converted to $\mathrm{CH}_{4}$ portioned of $72 \%$ on acetate fermenters and $28 \%$ on hydrogen oxidizers. Theoretical methane yield based on element compounds is shown in Table 6 and Fig. 3. Excluding ST values, modified theoretical methane yield based on VS in LF showed a tendency of reduction pig [15]; Pig 1: 25-60-day breeding pigs, Pig 2: 60-116 days, Pig 3: 116-189 days-before shipping to butchery, Pig 4: sows (including pregnant pigs)

according to flows of pig breeding period from Pig 1 to Pig 4 in Fig. 3A. In contrast, modified theoretical methane yield based on VS at ISF had lower values ranging from 0.26 to $0.35 \mathrm{Sm}^{3} \mathrm{CH}_{4} / \mathrm{kg}$ VS. The mean values of TMY $(\mathrm{m})$, total sum of theoretical methane yield modified with generic parameters of methanogens (acetate fermenters and hydrogen oxidizers), based on VS were $0.39 \mathrm{Sm}^{3} \mathrm{CH}_{4} / \mathrm{kg}$ in LF and $0.30 \mathrm{Sm}^{3} \mathrm{CH}_{4} / \mathrm{kg}$ in ISF (Table 6). However, theoretical methane yields showed identical results in spite of 
Table 7 Comparison of characteristics of swine manure in Korea and Germany

\begin{tabular}{|c|c|c|c|c|}
\hline & $\begin{array}{l}\text { Input swine manure into } \\
\text { in situ facilities (A) }\end{array}$ & $\begin{array}{l}\text { Swine manure from } \\
\text { livestock farms }(B)\end{array}$ & $\begin{array}{l}\text { Case of Germany (swine manure into } \\
\text { in situ facilities) }(\mathrm{C})^{\mathrm{a}}\end{array}$ & $\begin{array}{l}\mathrm{B} / \\
\mathrm{A}\end{array}$ \\
\hline TS $(\%)$ & 3.86 & $10.6(3.2-16.8)$ & $16.8^{\mathrm{d}}$ & 2.7 \\
\hline CODcr $\left(\mathrm{mg} \mathrm{L}^{-1}\right)$ & 49,133 & 121,583 & - & 2.5 \\
\hline $\begin{array}{l}\text { Organic constituents (protein, fat and } \\
\text { carbohydrate) }(\mathrm{g} / 100 \mathrm{~g})^{\mathrm{b}}\end{array}$ & 5.12 & 10.9 & - & 2.1 \\
\hline $\mathrm{C} / \mathrm{N}$ ratio $^{\mathrm{c}}$ & 9.5 & 14.9 & & 1.6 \\
\hline VFAS $\left(\mathrm{mg} \mathrm{L}^{-1}\right)$ & 6808 & 16,047 & & 2.4 \\
\hline Organic loading rate $\left(\mathrm{kg} \mathrm{VS} / \mathrm{m}^{3}\right.$ day) & 0.95 & $2.67^{\mathrm{e}}$ & $1.98^{\mathrm{d}}$ & 2.8 \\
\hline $\begin{array}{l}\text { Removal efficiency of organic } \\
\text { materials (based on VS) }\end{array}$ & $43.1 \%$ & - & - & - \\
\hline Methane yield $\left(\mathrm{m}^{3} \mathrm{CH}_{4} / \mathrm{kg} \mathrm{VS}\right)$ & 0.31 & $0.40^{\mathrm{f}, \mathrm{g}}$ & - & 1.3 \\
\hline Methane yield $\left(\mathrm{Nm}^{3} \mathrm{CH}_{4} /\right.$ ton $)$ & $6.69^{\mathrm{h}}$ & $18.37^{\mathrm{f}, \mathrm{g}}$ & $17.0(12-21)^{\mathrm{h}}$ & 2.7 \\
\hline
\end{tabular}

${ }^{\mathrm{a}}$ In Germany, in situ biogasification facilities are generally located near the livestock farms. Swine manure generated from livestock farms is supplied directly to the in situ facilities

${ }^{\mathrm{b}}$ Organic constituent: total sum of carbohydrate, protein and fat

${ }^{\mathrm{c}}$ Appropriate $\mathrm{C} / \mathrm{N}$ ratio for biogasification: $12-30$

${ }^{\mathrm{d}}$ This value is average for five in situ facilities treating swine manure (including combination with bio-crops)

${ }^{\mathrm{e}}$ This value is multiplied with $7.89 / 2.81$ to OLR in in situ facilities

${ }^{\mathrm{f}}$ Theoretical methane yield applying the results of element analysis

${ }^{\mathrm{g}}$ Standard gas removed moisture (apply average $77 \%$ at room temperature and actual atmospheric pressure)

${ }^{\mathrm{h}}$ Guideline of biogasification in Germany, 2013[13]

dissimilarity in elements component among pre-treated swine manure samples.

Figure 3B illustrates results of theoretical methane yield based on ton of swine manure. In stark contrast with $\mathrm{TMY}_{\mathrm{LF}}$ in Fig. 3A, modified theoretical methane yield based on ton of swine manure in LF tended to increase in accordance with the flow of pig- breeding period from Pig 1 to Pig 4. The average theoretical methane yields were 31.0 $\mathrm{Sm}^{3} \mathrm{CH}_{4} /$ ton $_{\mathrm{SM}}$ in LF and 8.3 $\mathrm{Sm}^{3} \mathrm{CH}_{4} / \mathrm{ton}_{\mathrm{SM}}$ in ISF. Comparing the average between LF and ISF, TMY ISF based on ton of swine manure was $26.7 \%$ of TMY in LF sources. Through these results, most of theoretical methane yields in LF had relatively larger values than in ISF except for values of TMY based on CODcr.

\section{Comparison on characteristic of swine manure between Korea and Germany}

Table 7 presents the comparison of characteristics of swine manure in LF and ISF in Korea and Germany. Like aforementioned in introduction part, EU, especially in Germany, shows high organic compounds and biogasification efficiency of swine manure than Korea [13]. The reason for those results is that swine manure in Germany has almost no difference in properties between incoming ISF and generating LF since being sent to the biogasification facilities immediately after generation from LF. When comparing the organic concentrations of swine manure in the ISF between Korea and Germany, the values of Germany (C) had high organic compounds (TS and CODcr) at least 1.5 times of Korea (B) shown in Table 7. In Korea, swine manure sent to ISF (A) was approximately 2.5 times lower than swine manure generated from LF (B). Methane yield based on ton of swine manure was $6.69 \mathrm{Nm}^{3} \mathrm{CH}_{4} /$ ton (A), $18.37 \mathrm{Nm}^{3} \mathrm{CH}_{4} /$ ton (B) and $17.0 \mathrm{Nm}^{3} \mathrm{CH}_{4} /$ ton (C). It was estimated that it is necessary to inject a high concentration of swine manure into facilities for elevating the efficiency of biogasification (including methane yield) like Germany cases in Table 7.

Acknowledgments This work was supported by the National Research Foundation of Korea (NRF) Grant funded by the Korea government (MSIP), [NRF-2017R1A2B4004635] and the Fund for New Professor Research Foundation Program (2016-0198), Gyeongsang National University, 2016.

\section{References}

1. Korean Ministry of Environment (KMOE) (2008) Economic analysis of waste-to-energy project. KMOE, Waste-to-Energy Division, South Korea

2. KMOE (2014) Statistics of swine manure treatment. KMOE, Watershed and Total Load Management Division, South Korea 
3. STATISTICS Korea (2014) Investigation report of agriculture, forestry and fisheries. STATISTICS Korea, South Korea

4. Kim SU, Owens VN, Kim SY, Hong CO (2017) Effect of different way of bottom ash and compost application on phytoextractability of cadmium in contaminated arable soil. Appl Biol Chem 60(4):353-362

5. Park WK, Park NB, Shin JD, Hong SG, Kwon SI, Kang KK (2011) Study on characteristics of biogas production and liquid fertilizer with anaerobic co digestion of livestock manure and food waste. Korean J Soil Sci Fert 44(5):895-902

6. Shin JD, Hong SG, Lee SI, Hong SC, Lee JS (2017) Estimation of soil carbon sequestration and profit analysis on mitigation of $\mathrm{CO}_{2}$-eq. emission in cropland cooperated with compost and biochar. Appl Biol Chem 60(4):467-472

7. Yoon YM (2013) Status and development way of biogas production technology and policy using livestock waste. J KORRA 21(2): $18-40$

8. Ministry of Agriculture, Food and Rural Affairs (MAFRA) (2013) Long-term countermeasure of waste-to-energy of swine manure. MAFRA, South Korea

9. MAFRA (2009) Action plan of energization of swine manure. MAFRA, Livestock Policy Division, South Korea

10. KMOE (2015) Status of organic waste energy utilization facilities. KMOE, waste resource and energy division, South Korea

11. KMOE (2007) Comprehensive plan of energization and land disposal of food waste leachate. KMOE, Municipal Solid Waste Division, South Korea

12. KMOE (2012) Research on improvement and management policy of food waste. KMOE, Waste Resources Management Division, South Korea

13. National Institute of Environmental Research (NIER) (2014) Guideline of biogasification in Germany. NIER, Waste-to-Energy Research Division, South Korea

14. KMOE (2015) Official waste testing method, ES06301.1a. KMOE, NIER, Environmental Measurement and Analysis Center, South Korea, pp 57-60

15. Korea Pork Producers Association (KPPA) (2009) Guideline of piggery farm. KOME, Water Environment Policy Division, South Korea
16. American Public Health Association (APHA) (2005) American Water Works Association, Water Environment Federation, Standard method for the examination of water and wastewater, 22nd edn. APHA, Washington

17. KMOE (2015) Official testing method with respect to water pollution process, ES 04363.1a, ES 04355.1b, ES 04362.1b, ES 04360.2b. KMOE, NIER, Environmental Measurement and Analysis Center, South Korea, pp 302-405

18. Ministry of Food and Drug Safety (MOFDS) (2015) Official food testing method, general testing method 1.1.3.1., B. Methods using the protein analyzer. MOFDS, South Korea

19. MOFDS (2015) Official food testing method. General testing method 1.1.5.1.1., Ether extraction method. MOFDS, South Korea

20. Tchobanoglous G, Theisen H, Vigil S (1993) Integrated solid waste management. McGraw-Hill, Pennsylvania

21. Shin JD, Hong SG, Kim SC, Yang JE, Lee SR, Li FZ (2016) Estimation of potential methane production through the mass balance equations from agricultural biomass in Korea. Appl Biol Chem 59(5):765-773

22. Lee DJ, Bae JS, Seo DC (2017) Effect of seasonal variations of organic loading rate and acid phase on methane yield of food waste leachate in South Korea. Appl Biol Chem 60(1):87-93

23. Rittmann BE, McCarty PL (2001) Environmental biotechnology: principles and applications. McGraw-Hill Book Co., New York

24. Gujer W, Zehnder AJB (1983) Conversion processes in anaerobic digestion. Water Sci Technol 15(8-9):127-167

25. Park BK, Ryu HD, Ahn KH, Kim SJ, Choi SA, Shin DS, Park JH, Kim HT, Kim YS, Rhew DH, Oa SW (2014) The study on the status of resource recovery system of livestock manure. National Institute of Environmental Research (NIER), NIER RP2014-320

26. Hansen KH, Angelidaki I, Ahring BK (1998) Anaerobic digestion of swine manure: inhibition by ammonia. Water Res 32(1):5-12

27. Ahring BK, Sandberg M, Angelidaki I (1995) Volatile fatty acids as indicators of process imbalance in anaerobic digesters. Appl Microbiol Biotechnol 43(3):559-565

28. Chen Y, Cheng JJ, Creamer KS (2008) Inhibition of anaerobic digestion process: a review. Bioresour Technol 99(10):40444064 